\title{
From Participatory Democracy to Digital Democracy
}

\author{
Mark Kann
}

Tom Hayden posted on his website, http://www.tomhayden.com, an article he coauthored with Dick Flacks to commemorate the fortieth anniversary of the Port Huron Statement. The two SDS founders concluded, "Perhaps the most important legacy of the Port Huron Statement is the fact that it introduced the concept of participatory democracy to popular discourse and practice." The concept of participatory democracy encompassed values such as equality, decentralization, and consensus decision-making. It provided direction for "all those trying to create a world where each person has a voice in the decisions affecting his or her life." [1] In this article, I suggest that Port Huron's concept of participatory democracy included some ideas that were potentially antithetical to democracy and that potential, unfortunately, is being fulfilled in contemporary theories of digital democracy.

\section{The Port Huron Statement Revisited}

The Port Huron Statement contained two underlying themes that potentially subverted democratic equality. One was the notion that the American people were fundamentally flawed, most apparently, by their apathy. The other was that the best means to eliminate this flaw was to follow the lead of rational, deliberative activists. Both themes could be (and would be) used to justify political inequalities.

Port Huron's student-authors expressed a dim view of American citizens. The American people had closed minds. They exhibited a foolish confidence that the nation could muddle through its problems. They harbored a false sense of contentment, "a glaze above deeply felt anxieties," arising out of loneliness, isolation, and estrangement. They also suffered from materialism, meaningless work, and an intellectual numbness born of powerlessness. Overall, the students portrayed Americans as a people more prone to ignorance, silence, and obedience to their leaders than to equal participation in the decisions that affect their lives. [2]

The good news was that Americans could be redeemed. They had a capacity for self-cultivation, selfunderstanding, and creativity. They could become engaged in a community founded on love, thoughtfulness, and creativity. Importantly, students in universities ("overlooked seats of influence") could lead the way. College students who developed "real intellectual skill" and committed themselves to reason, reflection, and deliberation were the basis for a New Left that would impart information, enhance motivation, and encourage participation.

To a degree, then, the student-authors assumed that Americans suffered false consciousness. The students were not clear on whether they expected people to overcome false consciousness before they became actively involved in politics or whether people would become enlightened by way of their active involvement in politics. Nor did the authors gauge "how false" American consciousness was or how false it was in comparison to common political practices and hegemonic ideas disseminated by dominant elites. The omission was significant. It sidestepped the question of whether the American people - as they thought and acted at the time-could be trusted to participate in the politics of self-government.

One can infer from the Port Huron Statement an indirect answer to the question of trust. On the one hand, 
the SDS writers suggested that, alas, the American people could be trusted to participate in politics in ways that supported dominant elites. They essentially portrayed the United States as a plebiscitary democracy in which a combination of citizen apathy and periodic elections legitimized government by the few. On the other hand, the Port Huron Statement implied that American people could not yet be trusted to exhibit the love or deliberation essential to a robust, participatory democracy. Certainly, later SDS activists did not endorse Richard Nixon's racist, xenophobic "silent majority" when it became more vocal and more involved in political discussion and decision-making. A strong temptation for New Left activists was to proclaim themselves the arbiters of what counted as love and deliberation as a basis for determining who could be trusted to participate in public life.

Overall, I believe that the Port Huron Statement was based on an optimism that a majority of Americans eventually would participate in politics in ways that enhanced liberty, equality, community, the common good, and world peace. Nevertheless, its dim assessment of American public consciousness, along with its emphasis on deliberation as the proper foundation for participation, fueled the arguments of later activists who declared themselves a political vanguard. Nearing the end of the 1960s, pessimism about the American people and optimism about activists' insight produced significant antidemocratic tendencies within the New Left.

Michael Walzer concluded the decade with a marvelous essay about participation in progressive politics. He made several key points. First, a citizen's choice not to participate does not constitute false consciousness. There are many legitimate reasons for citizens to disengage themselves from politics. Equally important, these nonparticipants play an important role in democracy. They serve as audiences and critics of participants. Furthermore, they are citizens who have rights and interests that need to be represented. Walzer wrote, "Participatory democracy needs to be paralleled by representative democracy." Second, participatory democracy has a tendency to become "the rule of men with the most evenings to spare." Activists often turn participation into an onerous "duty" that entails constant meetings, discussions, deliberations, and decision-making. That duty may become so burdensome that most citizens cannot conceivably do it and many activists burn out trying. The "participatory" element in participatory democracy may disappear when the few activists who are willing to give 110 percent to the cause monopolize among themselves political initiative, strategy, and authority. Walzer warned that the most committed participants are the ones who need the strongest reminder that they are only part of the citizenry. [3]

\section{Participatory Democracy in Practice}

In 1977, Tom Hayden founded the Campaign for Economic Democracy (CED), which he dedicated to giving the public "a real voice" in economic and political decisions." [4] Hayden lived in Santa Monica, California, where the local CED chapter joined a municipal coalition (Santa Monicans for Renters' Rights-SMRR) to win a major rent control referendum in 1979 and then control of city hall in 1981. Progressive activists and public officials hoped to bring participatory democracy to the city. I have told their story in Middle Class Radicalism in Santa Monica (1986). Here I focus on three tensions that emerged when progressives sought to implement participatory democracy in an affluent, ocean side city. [5]

First, activists and politicians had a tough time adhering to the concept of participatory democracy. For example, the SMRR coalition championed the participation of residents living in the low-income, minority section of town, but the coalition's white, middle-class activist leaders did not especially trust those residents or their neighborhood association to adhere to SMRR's agenda. The residents were outsiders. Their priorities and interests differed from those of the rent-control crowd. Activists also supported broad citizen participation on city commissions. However, they opened commissions to diverse participation only after they appointed trusted allies who could secure a majority and control decision-making outcomes. The result was that more low-income minorities participated in local politics and were served by city government but they did not necessarily win greater influence over public policy. Clearly, activists' rhetoric outran their success in putting participatory democracy into practice.

Second, political activists and politicians became increasingly dependent on professionals and experts to administer rent control, guide public policy, and insure electoral majorities. After 1979, a rent control board with its own legal staff administered rent control and adjudicated landlord-tenant disputes. The city attorney and the city manager defended progressive victories but they also resisted a number of progressive policies. Periodic elections prompted activist politicians to appeal to their renter base and downplay other progressive issues as potentially divisive. The elections also prompted SMRR candidates to hire professional consultants to devise and manage their 
electoral campaigns. To a large extent, the democratic goal of citizen participation did not stand in the way of structural forces that were conducive to amateur demobilization, issue depoliticization, and the reign of professional expertise.

Third, SMRR leaders and politicians made extraordinary demands on the time, energy, and resources of the activist community. For example, the mayor remained voluntarily unemployed, turning what had been a part-time job into an overtime commitment. Leaders put tremendous pressure on activists to attend endless meetings-night after night and on weekends. Why? Egalitarian, decentralized, inclusive, consensus decision-making takes an enormous amount of time. City council meetings, municipal commission and board meetings, neighborhood organization meetings, CED meetings, Democratic Club meetings, SMRR meetings, and so on, were ongoing and unending. Moreover, because progressive leaders tended to distrust those outside their own ranks, they took on more and more tasks themselves and they demanded more and more time from the activist rank and file. Those who put in the time were likely to become part of the activist core; those who "failed" in their duty were apt to end up on the periphery. The tendency here was for the "last activists standing" to practice participatory democracy among themselves-while everyone else went to bed.

To their credit, Santa Monica activists did not make a virtue out of necessity. They did not declare their moral or intellectual superiority over those whom they governed; they did not justify the rule of deliberative experts at the expense of citizen amateurs; and they did not try to force on the unwilling a sacred duty to participate. Indeed, many student activists of the 1960s and backyard democrats of the 1980s recognized the tension between participatory ideals and structural obstacles. Santa Monica activists did want lower-class minorities to organize, participate, and share in governance; they did want to give preference to political mobilization and progressive policies while taking advantage of the advice of experts; and they did want to build a culture in which participation was inclusive and fulfilling rather than onerous and burdensome. In contrast, today's "digital democrats" often resolve these tensions in ways that systematically undervalue and substantially undermine democratic participation.

\section{| Participation in Cyberspace}

The recent development and deployment of the Internet invited participatory democrats to adapt their theories to twenty-first century technology. Tom Hayden was near the head of the line. He developed his own interactive website which includes, among other features, "Tom's Blog" as well as a "Discussion Forum" advertised as "the place to ask Tom a question." [6]

The Internet seems to be ideally suited to participatory democracy in the United States. It is a decentralized technology devoid of gatekeepers and subversive of hierarchy. It provides millions of citizens with relatively cheap and easy access to massive amounts of social and political information as well as to unmediated, interactive communication with other citizens and leaders. It can host virtual town hall meetings, close the distance between voters and decision-makers, and serve as a medium for mounting protests against social injustice and political corruption. Amitai Etzioni writes, "It would be much easier online than offline for millions not merely to gain information and to vote, but also to participate in deliberations and in instructing their chosen representatives." [7] Welcome to the age of digital democracy.

Note that even the most enthusiastic digital democrats recognize obstacles to online participation. The Internet is a commercialized medium, more suited to the desires of consumers and producers than to the needs of citizens and decision-makers. The Internet generates a "digital divide" that reproduces many of the inequalities that exist in society, with the "haves" making more effective use of cyberspace than the "have nots." Furthermore, the Internet tends to isolate individuals from each other, promote fragmented and parochial publics, and give preference to information dissemination, polling, and voting rather than democratic discussion, deliberation, and decision-making. Digital democrats exhibit different degrees of confidence about the possibilities for overcoming these obstacles but they still believe that the Internet can be a positive, potent force for promoting democratic participation. [8] Is their confidence justified?

Much of the discourse on digital democracy is based on a low opinion of the American people's capacity for self-government. Theorists rarely refer back to Thomas Paine's belief in the people's "common sense" or even to Thomas Jefferson's faith that average citizens can govern themselves in local communities. Instead, digital democrats' useable past focuses on James Madison, whose writings emphasized people's inordinate passions, selfish interests, 
frequent factionalism, and tendency toward tyrannical majorities. [9] In one sense, digital democrats' resurrection of Madison is surprising. A major thrust of Madison's contributions to the Federalist was opposition to democratic experiments in the states in favor of centralized power in a national government that would be governed by "the better sort." In another sense, Madison's popularity among digital democrats is almost predictable. Many cyberdemocrats fear that the Internet will be used primarily as an instrument for instant polling, instant referenda, instant electionsthat is, for instant democracy. Like Madison, these digital democrats fear plebiscitary democracy, which Benjamin Barber defines as "a democracy that embodies majority opinions assembled from the unconsidered prejudices of private persons voting private interests." Digital democrats have little faith in the common sense, good will, or civic virtue of the American majority; indeed, they dwell on the people's impulsive, prejudicial opinions and worry about "unchecked majoritarianism." [10]

This lack of faith in the American public seems to have two sources. One source, as old as Madison, is a belief that Americans' fickle combination of apathy, passion, selfishness, consumerism, and parochialism-when unmediated by built-in delays and buffers, countervailing forces, and governing elites-tends to produce social disorder, bad public policy, and majority tyranny. The other source is digital democrats' conviction that populist measures such as citizen referenda and popular plebiscites regularly produce conservative victories. Especially since the Reagan Revolution, progressive democrats fear that America's "unthinking" majority supports illiberal, undemocratic values founded on a combination of religious fundamentalism and laissez-faire capitalism. They worry that populist appeals produce California-style initiatives that serve the cause of moral regulation and social inequality, and invite public support for popular demagogues (reminiscent of Hitler and Mussolini). Unfortunately, digital democrats conclude, if the Internet facilitates plebicitary democracy and makes "push-button democracy" pervasive, the result will be to empower conservative policies and demagogues strongly opposed to equality. Lloyd Morrissett concludes that the choice today is "demagoguery or democracy." [11]

To avoid the demagoguery born of "mass prejudice" and "the tyranny of opinion" and instead to achieve "strong democracy," Barber argues that the Internet should become a forum for a "multiple-phase" process of public deliberation that includes "information, adversarial debate, and the direct engagement of citizens within their local communities, and among the communities and the experts." The Internet should be reconceived and reengineered as a Civic Net rather than a Commercial Net. It should serve as a source not so much of information as knowledge, the latter requiring time for discussion, debate, and deliberation. Meanwhile, "netizens" ought to be taught the skills necessary for expressing and defending their views in public forums and for listening and responding to other people's views, even to views they would prefer to ignore. Ideally, digital democrats tell us, we should move toward "a discursive democratic polity" in which the voice of the people is heeded in decision-making not because it is the voice of the people but because it conveys a thoughtful message. [12]

Let us assume the plebiscitary democracy will result in policies and laws consistent with right wing populism. Is the problem that the American people suffer from false consciousness because they are more interested in pornography than politics or because they tolerate or support dominant elites? [13] Is it that they lack proper motivation to participate or proper information and sufficient deliberation? Not necessarily. It may be that many Americans agree with libertarian norms founded on a distrust of politics or conservative values aimed at enforcing fundamentalist morality. And it may be that many Americans believe that an impassioned citizenry needs to be governed because it is incapable of governing itself in an orderly fashion. The problem may not be plebiscitary democracy; the problem may be the assumptions, values, and preferences that many Americans bring to politics. Perhaps digital democrats should be less concerned with push-button technology and their own role as the arbiters of deliberative outcomes; they should be more concerned with winning the hearts and minds of the American people.

Alternatively, let us assume that plebiscitary democracy invites impulsive decisions that tend to produce varying degrees of social disorder, bad public policy, and majority tyranny. Consider Richard K. Moore's description of West Coast populism:

In California, there has long been an initiative and referendum process, and it is much used. This particular system was set up in a fairly reasonable way, and in many cases decent results have been obtained. On the other hand, there have been cases where corporate interests have used the initiative process (with the help of intensive advertising campaigns) to get measures approved that were blatantly unsound.[14]

Moore sets himself up as the arbiter of what counts as "decent results" and "blatantly unsound" measures without either justifying his authority to arbitrate or making a case for his substantive position. His implicit message is, "Trust 
me rather than California voters or the corporate interests that manipulate them." Conceivably, the majority of California voters who supported corporate interests and their pet policies were actually making thoughtful decisions that were consistent with their own values and preferences.

Even if one grants the argument that the American people tend to use plebiscitary democracy to make impulsive decisions that produce varying degrees of social disorder, bad public policy, and majority tyranny, one must compare those likely results with the actual results produced by the current system of representative government. Today, American citizenship combines public inaction and periodic voting to produce conservative Republican domination in all three branches of the federal government, ongoing social inequalities, public policies destructive of people's civil rights and economic opportunities, and what some consider a rising rightwing tyranny (symbolized by the Patriot Act). In contrast, a plebiscitary democracy, with all of its flaws, might be preferable to this right wing domination. Indeed, online participation in a plebiscitary democracy may even constitute a significant step toward building more participatory mobilizations and progressive organizations.

The most progressive digital democrats generally argue that the solution to the public's shortcomings involves devising a way for citizens to deliberate on public issues. According to Barber, the transition from ill-informed public opinion to deliberative public knowledge is likely to require "intervention, education, facilitation, and mediation-all anathema of devotees of an anarchic and wholly user-controlled net whose whole point is to circumvent facilitation, editing, and other 'top-down' forms of intervention." [15] Barber believes that citizen deliberation is so crucial to fostering participatory democracy that efforts to facilitate it may require the imposition of government regulation of the Internet.

If we grant the importance of deliberation for democracy, it may still be the case that deliberation is not a sufficiently weighty value to justify government regulation of the Internet. Deliberation does not rule out deceit, but it may promote manipulation. Deliberation does not eliminate inequalities in people's motivation, education, resources, and bargaining power. Deliberation does not guarantee fair treatment, good will, or consensus decision-making. Nor does deliberation ensure that a majority will not be as tyrannical as, if not more tyrannical than, an impulsive citizenry. What deliberation does ensure is a degree of hierarchy in which those who participate in public forums are likely to claim superior political credentials to nonparticipants. Are we prepared to exclude nondeliberative citizens from political participation? Are we to assume nondeliberative citizens will be virtually represented by deliberative netizens? [16]

Even if we were to agree that deliberation is sufficiently important to justify top-down governance of the Internet, we must ask who is appropriately qualified and trustworthy to design and administer top-down governance. Digital democrats cannot depend on the American people; after all, they are the ones in need of guidance. Nor can digital democrats count on dominant elites, who benefit from the absence of deliberative, participatory democracy. According to Bruce Bimber, the complexity of the Internet and modern governance systematically undermines the public's capacity "to participate in the formation of political agendas, engage in the policy process, and monitor and ultimately control democratic institutions." Instead, this complexity provides "experts" a technical and political advantage over the public, making democracy "vulnerable to drift toward a state of Platonic guardianship." For Bimber, the question is whether a sufficiently savvy subset of informed and engaged citizens (net activists?) can counterbalance the inevitable power of experts. [17] Here, participatory democracy is less a political ideal than a stopgap measure to energize an activist vanguard to check and balance technocratic domination.

Digital democrats do not seem to be particularly concerned with attracting or building a social base that might participate in a mobilization or movement aimed at promoting digital democracy. On the one hand, the theorists seem more comfortable confronting technical obstacles to digital democracy than engaging in a social and political analysis of the forces that might benefit from it, support it, and lead the way to it. For example, in considering how to insure that "e-democracy [does] not turn demagogic," Etzioni explains how to transform chat rooms into deliberative forums by installing "delay loops." Missing is an analysis of the social forces that may advocate or participate in these deliberative forums. [18] On the other hand, digital democrats are happy to provide examples of progressive groupslocally, nationally, and internationally-that have used the Web to promote grassroots organizing, coordinate coalitions and protests, and identify and publicize political corruption. Of course, conservatives and fascists have also used the Web, perhaps more aggressively, to promote their own visions, values, and causes.

An important difference distinguishing the Port Huron students and Santa Monica activists from today's digital democrats is proximity to a social base. SDS was part of a student movement and the Port Huron Statement was a catalyst for the growth of that movement. Santa Monica's progressives led a renters' revolt in a city where some 
$80 \%$ of residents were tenants and where a struggle for control over one's housing was seen as a launching pad for a broader movement to win democratic control of the community. A major problem facing digital democrats is that they have not identified a social base. As far as I can tell, the main audiences for their theories, ideas, and recommendations are other professionals and experts: academics, politicians, bureaucrats, and industry practitioners. [19]

\section{| A Politics for Digital Democracy?}

In a fascinating think piece, John Ferejohn argues that Americans live in a participatory democracy but do not realize it. While public interest and participation in conventional political institutions is quite low, civic engagement in associational life (including the workplace) is relatively robust. This form of participation fortifies individuals' principled belief in social equality and cooperation and it fuels periodic "participatory eruptions" that shatter people's everyday complacency and draws them into populist surges focused on a variety of public issues. [20]

Ferejohn emphasizes political principles and participatory eruptions, which are also important to Dick Flacks and Tom Hayden when they reflect on the legacy of the sixties and evaluate the prospects for the future. Flacks and coauthor Jack Whalen conclude a study of the evolving ideals of the sixties generation as its activists matured into adulthood by writing:

The lives we have looked at in this inquiry ... have been deeply affected by their intertwining with social movement. The flow and ebb of collective action is the primary context within which lives committed to principle are lived. It is not that in ebb times principles are abandoned, for what we have found is different. But it is the case that personal conviction is insufficient to make commitment fully meaningful. The spirit of the sixties did not die as its bearers got older, nor did they betray that spirit. Perhaps the spirit waits for a new opportunity that will permit the tide of collective action once more to rise. [21]

This focus on enduring principles and changing contexts, it seems to me, is crucial for understanding opportunities for promoting participatory democracy. The struggle for participatory democracy is still a fight for principles, particularly for the enduring value of equality and self-government. Deliberation is an important principle but not necessarily a primary one. The Internet can be an important medium for fostering both involvement and deliberation but the medium is neither the message nor a substitute for it. The struggle for the hearts and minds of citizens is an ongoing one-regardless of changes in information and communication technologies.

Principles do not exist in a social vacuum. In a 2003 speech posted on http:/ / alternet.org, Tom Hayden offers evidence of the rise of "a new movement in the world." One of its strands is "the global justice movement." Another main strand is global opposition to America's war in Iraq, which is emblematic of our elites' imperial designs. The main manifestation of this new movement is periodic participatory eruptions such as the Seattle protests against the World Trade Organization or the rapid rise of http://www.MoveOn.org as a factor in domestic politics. In both instances, the Internet proved to be an effective instrument for mobilizing participants and giving visibility to collective action. [22]

The cause of participatory democracy is not necessarily furthered by academic and practitioner emphases on online dissemination of information, online plebiscites, online deliberative forums, and online modes of decisionmaking. Rather, promoting participatory democracy is still a matter of advocating democratic values and applying them to salient issues - using traditional means as well new media. However, as Roger Hurwitz suggests, an important function of cyberspace for democracy becomes visible during moments when there is "great dissatisfaction with a current state of affairs" and when that dissatisfaction finds expression in "ad hoc protest movements." These are moments when citizens do not need much information or forums for deliberation; rather, they need a focal point for "collective demand." During these participatory eruptions, the Internet can serve as a crucial medium for alerting citizens to the crisis and directing them to opportunities to engage in collective action. 


\section{Endnotes}

1. Hayden, Tom and Dick Flacks. "The Port Huron Statement at 40." http://www.tomhayden.com/ SocMov.1.html. Accessed December 8, 2004.

2. Students for a Democratic Society. 1969. "The Port Huron Statement." Pp. 1-15 in How Democratic is America? Responses to the New Left Challenge, edited by Robert A. Goldwin. Chicago: Rand McNally.

3. Walzer, Michael 1970. "A Day in the Life of a Socialist Citizen." Pp. 229-238 in Obligations: Essays on Disobedience, War, and Citizenship, edited by Michael Walzer. New York: Simon \& Schuster.

4. Campaign for Economic Democracy. Hayden, Tom. 1980. "Founding Statement, February 1977." P. 304 in The American Future: New Visions Beyond Old Frontiers. Boston: South End Press.

5. Kann, Mark E. 1986. Middle Class Radicalism in Santa Monica. Philadelphia: Temple University Press.

6. See http://www.tomhayden.com, retrieved on March 14, 2005.

7. Etzioni, Amitai. 2003. "Are Virtual and Democratic Communities Feasible?”

P. 97 in Democracy and New Media edited by Henry Jenkins and David Thorburn.Cambridge, MA: MIT Press.

8. Some good anthologies about digital democracy (in addition to Jenkins and Thorburn's Democracy and New Media) are: Hague, Barry N. and Brian D. Loader, eds. 1999. Digital Democracy: Discourse and Decision Making in the Information Age. London: Routledge.; Anderson, David M. and Michael Cornfield, eds. 2003. The Civic Web: Online Politics and Democratic Values. Lanham, MD: Rowman \& Littlefield.; Kamarck, Elaine and Joseph S. Nye Jr., eds,. 2002. Governance.com: Democracy in the Information Age. Washington, D.C.: Brookings Institution Press.

9. Cass Sunstein, republic.com (Princeton: Princeton University Press, 2001), 38-39; Joseph S. Nye Jr., "Information Technology and Democratic Governance," in Kamarck and Nye, 11-13; Arthur Isak Applbaum, "Failure in the Cybermarketplace of Ideas," in ibid., 27; Anthony G. Wilhelm, "Civic Participation and Technology Inequality: The 'Killer Application' is Education," in Anderson and Cornfield, 118-19. A major exception is Benjamin Barber, who attaches Jefferson's name to a model of "strong democracy" but, as we shall see, whose concern with popular participation is qualified by his prioritization of deliberation. See Barber, Benjamin. Winter 1998-1999. "Three Scenarios for the Future of Technology and Strong Democracy." Political Science Quarterly 113, 4:573-589.
10. Anna Malina, "Perspectives on Citizen Democratization and Alienation in the Virtual Public Sphere," in Hague and Loader, 33; Barber, "Three Scenarios," 585.

11. Stephen Coleman, "Cutting Out the Middle Man: From Virtual Representation to Direct Deliberation," in Hague and Loader, 200, 210; Richard K. Moore, "Democracy and Cyberspace," in ibid., 57; Anthony G. Wilhelm, "Virtual Sounding Boards: How Deliberative is Online Political Discussion?" in ibid., 175; Lloyd Morrisett, "Technologies of Freedom," in Jenkins and Thorburn, 27, 31.

12. Barber, "Three Scenarios," 583-84; Benjamin R, Barber, "Which Technology and Which Democracy?" in Jenkins and Thorburn, 43, 46; Wilhelm, "Virtual Sounding Boards," in Hague and Loader, 155, 157-60, 175; see also Benjamin Barber, Strong Democracy: Participatory Politics for a New Age (Berkeley: University of California Press, 1984).

13. See Ellen Hume, "Resource Journalism: A Model for New Media," in Jenkins and Thorburn, 332-33, 336.

14. Richard K. Moore, "Democracy and Cyberspace," 56 (emphasis added).

15. Barber, "Three Scenarios," 586; see also Sunstein, 167.

16. See Applbaum, "Failure in the Cybermarketplace of Ideas," 23-28.

17. Bimber, Bruce. (2003). Pp. 240-241 in Information and American Democracy: Technology in the Evolution of Political Power. Cambridge: Cambridge University Press.

18. Etzioni, "Are Virtual and Democratic Communities Feasible?” Pp. 87-88, 95.

19. See Gregory G. Curtin, "Editorial: Defining the E-Government Transformation," Journal of E-Government 1, 1 (2004): 1-2.

20. John Ferejohn, "Participation and Democracy," January 2005, retrieved on March 8, 2005, from http://lawweb.usc.edu/cslp/conferences/demcoracy workshops/documents/ferejohn2_000.pdf.

21. Whalen, Jack and Richard Flacks. (1989) P. 283 in Beyond the Barricades: The Sixties Generation Grows Up. Philadelphia: Temple University Press.

22. Hayden, Tom. October 21, 2003. "Evidence of Things Unseen: The Rise of a New Movement." http:// alternet.org/story/17000. Accessed March 14, 2005. 
